\title{
Clinical and epidemiological characteristics of lung cancer cases in Qatar
}

W.H. Ibrahim, ${ }^{1}$ K.I. Rasul, ${ }^{2}$ A. Khinji, ${ }^{3}$ M.S. Ahmed ${ }^{2}$ and A. Bener ${ }^{4}$

$$
\text { ونيس حمد إبر اهيم، كاكل السريرية والوبائية لسرطان الرئة رسول، عائشة الخنجي قطر، محمد صادق أحمد، عبد الباري بنر }
$$

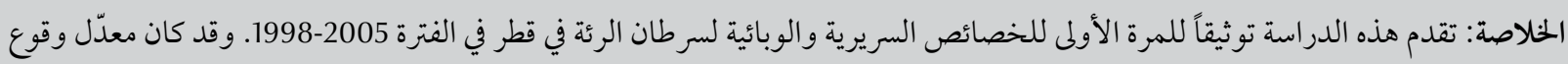

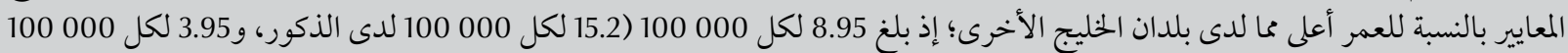

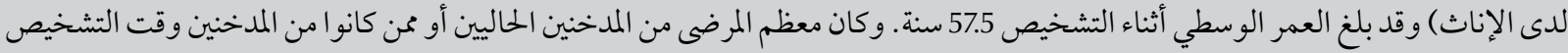

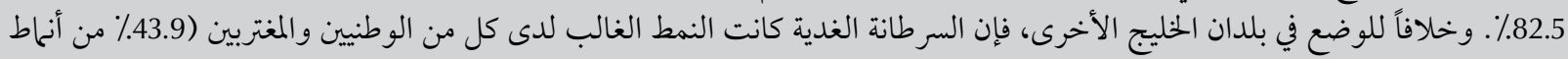

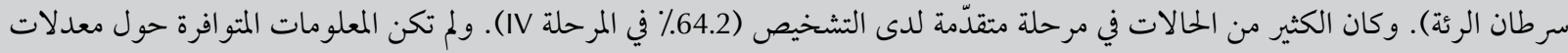
الوفيات كاملة بسبب هجرة المغتربين.

ABSTRACT This study documents for the first time the clinical and epidemiological characteristics of lung cancer cases in Qatar from 1998 to 2005. The age-standardized incidence rate was higher than that in many other Gulf countries: 8.95 per 100000 (15.2 per 100000 for males; 3.95 per 100000 for females). Mean age at diagnosis was 57.5 years. Most patients were current smokers or ex-smokers at the time of diagnosis (82.5\%). Unlike other Gulf countries, adenocarcinoma was the predominant type in both Qatari nationals and expatriates (43.9\% of lung cancer types). Many cases were in an advanced stage at diagnosis (64.2\% at stage IV). Incomplete information was available on mortality rate due to the migration of expatriates.

\section{Caractéristiques cliniques et épidémiologiques des cas de cancers du poumon au Qatar}

RÉSUMÉ Cette étude rassemble pour la première fois des données sur les caractéristiques cliniques et épidémiologiques des cas de cancer du poumon au Qatar entre 1998 et 2005. Le taux d'incidence standardisé sur l'âge était supérieur à celui observé dans de nombreux pays du Golfe : 8,95 pour 100000 (15,2 pour 100000 chez les hommes ; 3,95 pour 100000 chez les femmes). L'âge moyen au moment du diagnostic était de 57,5 ans et la plupart des patients (82,5\%) fumaient ou étaient d'anciens fumeurs. Contrairement aux autres pays du Golfe, l'adénocarcinome était le type prédominant (43,9\% des types de cancer du poumon), à la fois chez les Qatariens d'origine et chez les personnes expatriées. Lors du diagnostic, de nombreux cas étaient déjà à un stade avancé : $64,2 \%$ d'entre eux avaient atteint le stade IV. Les informations disponibles sur le taux de mortalité étaient incomplètes en raison de la migration des expatriés.

${ }^{7}$ Pulmonary Section, Department of Medicine; ${ }^{3}$ Internal Medicine Section; ${ }^{4}$ Department of Medical Statistics, Hamad General Hospital, Doha, Qatar(Correspondence to W.H. Ibrahim: wanisian@yahoo.com).

${ }^{2}$ Oncology Section, Al-Amal Hospital, Doha, Qatar.

Received: 27/06/07; accepted: 30/10/07 


\section{Introduction}

Lung cancer is currently the most frequently diagnosed major cancer and is the leading cause of cancer-related mortality in both men and women worldwide [1]. Cigarette smoke is the number one cause of lung cancer. About $90 \%$ of lung cancer cases occur in smokers or former smokers.

Qatar has an area of $11525 \mathrm{~km}^{2}$ with a total population of 885359 (July 2006 estimate). Foreign workers comprise $52 \%$ of the total population, mostly nationals from South Asia and other Arab countries and the Islamic Republic of Iran [2]. The prevalence of cigarette smoking in the Qatari population was estimated in a previous study to be $36.5 \%$ [3].

The aim of the present study was to document the clinical and epidemiological characteristics of lung cancer cases in Qatar. To our knowledge, this study is the first to address this subject in Qatar.

\section{Methods}

This was a retrospective, descriptive study of the clinical and epidemiological features of primary lung cancer cases in Qatar.

Data were collected from 2 sources: the Qatari national cancer registry database as well as through an extensive search of patient's medical records (computerized and noncomputerized) in the 2 hospitals providing oncology services in Qatar, Hamad General Hospital and Al-Amal Hospital (both part of Hamad Medical Corporation, the main health care provider).

Patients included in this study had been diagnosed with primary lung cancer during the period January 1998-December 2005 (inclusive) and were identified according to the $3 \mathrm{rd}$ edition of the International Classification of Diseases for Oncology (ICD-O-3) [4].
Epidemiological, clinical, diagnostic, therapeutic and mortality data on these cases were collected. The staging was based on the International Staging System for Lung Cancer [5].

The age-standardized incidence rate per 100000 population was calculated by direct standardization, using the world standard population. Valid percentages were calculated by excluding patients with missing information. Data were analysed using SPSS, version 15.

\section{Results}

A total of 203 cases of primary lung cancer were diagnosed in Qatar during the 8-year period 1998-2005. In 198 cases, histological confirmation of the diagnosis was performed and the histopathologic results were known; in a further 3 cases, histological confirmation was performed but the results could not be found; and in 2 cases the diagnosis was based on clinical and radiological features but no histological confirmation was performed. Therefore, microscopic verification of the lung cancer type was available in $97.5 \%$ of cases.

\section{Incidence}

As per 2002 statistics, lung cancer was the most frequently diagnosed cancer among males in Qatar, accounting for $12.1 \%$ of all cases. In females, lung cancer ranked 9th, accounting for $2.8 \%$ of all cancer cases in females diagnosed in that year.

The age-standardized incidence rate over the study period was estimated to be $8.95 / 100000$ population for the total population (15.20/100 000 for males and 3.95/100 000 for females).

\section{Demographic characteristics and smoking history}

The mean age at diagnosis was 57.5 years $(57.6$ years in males and 56.8 years in females). The age distribution of lung cancer patients in Qatar is shown in Table 1. Almost all cases (93.5\%) were

\begin{tabular}{|c|c|c|}
\hline \multicolumn{3}{|c|}{$\begin{array}{l}\text { Table } 1 \text { Demographic characteristics } \\
\text { of } 203 \text { patients diagnosed with lung } \\
\text { cancer in Qatar }\end{array}$} \\
\hline Characteristic & $\begin{array}{l}\text { No. of } \\
\text { patients }\end{array}$ & $\%$ \\
\hline \multicolumn{3}{|l|}{$\begin{array}{l}\text { Agegroup (years) } \\
(\mathbf{n}=200)^{a}\end{array}$} \\
\hline$<40$ & 13 & 6.5 \\
\hline $40-49$ & 43 & 21.5 \\
\hline $50-59$ & 53 & 26.5 \\
\hline $60-69$ & 49 & 24.5 \\
\hline $70-79$ & 39 & 19.5 \\
\hline $80+$ & 3 & 1.5 \\
\hline \multicolumn{3}{|l|}{$\operatorname{Sex}(n=201)$} \\
\hline Male & 178 & 88.6 \\
\hline Female & 23 & 11.4 \\
\hline \multicolumn{3}{|l|}{ Nationality $(\mathrm{n}=192)$} \\
\hline Qatari & 69 & 35.9 \\
\hline Non-Qatari & 123 & 64.1 \\
\hline \multicolumn{3}{|l|}{$\begin{array}{l}\text { Smoking history } \\
(\mathrm{n}=126)\end{array}$} \\
\hline Smoker/ex-smoker & 104 & 82.5 \\
\hline Never smoker & 22 & 17.5 \\
\hline \multicolumn{3}{|l|}{$\begin{array}{l}\text { No. packs of cigarettes } \\
\text { smoked/year }(\mathrm{n}=126)\end{array}$} \\
\hline$<20$ & 33 & 26.2 \\
\hline $21-40$ & 38 & 30.2 \\
\hline $41-60$ & 29 & 23.0 \\
\hline $61-80$ & 8 & 6.3 \\
\hline 81-100 & 12 & 9.5 \\
\hline $100+$ & 6 & 4.8 \\
\hline
\end{tabular}

${ }^{a}$ Data were missing in some categories.

diagnosed after age 40 years, and more than half were diagnosed between ages 50 and 69 years.

Most of the patients (88.6\%) were males; females accounted for only $11.4 \%$ (Table 1). Qatari citizens accounted for $35.9 \%$ of patients, while $64.1 \%$ were non-Qataris (Table 1).

A great majority of patients (82.5\%) were current or ex-smokers at the time of diagnosis: $30.2 \%$ smoked $21-40$ packs peryear, $26.2 \%<20$ packs, $23.0 \% 41-60$ packs and 53.2\% 21-60 packs (Table 1). In the male patients, $82.0 \%$ (146) were smokers compared to $92.0 \%$ (21) of female patients.

\section{Clinical presentation and diagnosis}

Cough was the most frequent chief presenting complaint in $35.7 \%$ of patients, followed by haemoptysis (14.3\%) and 
chest pain (11.9\%). Symptoms due to distant metastasis were the chief complaint in $11.9 \%$ of cases. About $8 \%$ of patients were asymptomatic at the time of diagnosis and the suspicion of lung cancer was based on incidental findings of abnormal chest radiograph or during workup for other reasons. Around 70\% of asymptomatic patients were nonQatari nationals (data not shown).

The most frequent symptoms associated with the chief complaint were cough in $69.6 \%$ of cases, weight loss in $44.4 \%$, chest pain in $37.3 \%$ and symptoms due to distant metastasis in $37.0 \%$ (Table 2).

Bronchoscopy was the most frequent method of confirming the diagnosis of lung cancer (in $40.8 \%$ of cases), followed by computerized tomographyguided transthoracic needle aspiration (36.8\% of cases) (Table 2).

\section{Tumour type and stage}

The site of the tumour was the upper lobe in $49.4 \%$ of cases, lower lobe in $26.6 \%$ and main bronchus in $18.2 \%$ of cases (Table 2).

Adenocarcinoma was the most common histological type (43.9\%), followed by squamous cell cancer $(25.8 \%)$ and unspecified non-small cell lung cancer (10.6\%) (Table 3). Analysis according to nationality showed that adenocarcinoma predominated in both Qataris and expatriates.

A majority of lung cancers were in an advanced stage at the time of diagnosis: $64.2 \%$ of cases were in stage IV and $14.8 \%$ were in stage III B (Table 2).

\section{Treatment received and mortality data}

As the majority of our patients were non-Qatari expatriates, most had left the country shortly after receiving the diagnosis of lung cancer in order to be treated in their own countries and to be near their families. Therefore, incomplete mortality data were available due to loss of follow-up. However, 67

\begin{tabular}{lll}
\hline Table 2 Clinical features of patients diagnosed with lung cancer in Qatar \\
\hline Clinical features & $\begin{array}{c}\text { No. of } \\
\text { patients }\end{array}$ & $\%$
\end{tabular}

\section{Chief presenting symptom $(\mathrm{n}=126)$}

Cough 45

Haemoptysis $\quad 18$

Chest pain

Symptoms due to distant metastasis $\quad 15 \quad 11.9$

$\begin{array}{lll}\text { Breathlessness } & 12 & 12\end{array}$

$\begin{array}{lll}\text { Asymptomatic } & 10 & 7.9\end{array}$

Weight loss $\quad 5 \quad 4.0$

Hoarseness $\quad 3 \quad 2.4$

Malaise $\quad 2 \quad 1.6$

Swelling in the chest $\quad 1 \quad 0.8$

Associated clinical features (other than chief complaint) ${ }^{a}$

$\begin{array}{lll}\text { Cough } & 87 & 69.6 \\ \text { Weight loss } & 56 & 44.4 \\ \text { Chest pain } & 47 & 37.3 \\ \text { Symptoms due to metastasis } & 44 & 37.0 \\ \text { Breathlessness } & 43 & 34.4 \\ \text { Malaise } & 33 & 26.2 \\ \text { Haemoptysis } & 32 & 25.4 \\ \text { Clubbing } & 16 & 12.1 \\ \text { Hypercalcaemia } & 15 & 11.1 \\ \text { Superior vena cava obstruction } & 11 & 7.9 \\ \text { Hoarseness } & 5 & 4.0\end{array}$

Site of tumour $(\mathrm{n}=154)$

$\begin{array}{lll}\text { Upper lobe } & 76 & 49.4\end{array}$

Lower lobe $\quad 41 \quad 26.6$

Main bronchus $\quad 28 \quad 18.2$

Bilateral $\quad 5 \quad 3.2$

Lingual $\quad 4 \quad 2.6$

Stage at diagnosis $(\mathrm{n}=162)$

$\begin{array}{lll}\mathrm{I} & 12 & 7.4\end{array}$

IIA $\quad 2 \quad 1.2$

$\begin{array}{lll}\text { IIB } & 9 & 5.6\end{array}$

$\begin{array}{llll}\text { IIIA } & 11 & 6.8\end{array}$

$\begin{array}{lrr}\text { IIIB } & 24 & 14.8\end{array}$

IV $\quad 104 \quad 64.2$

Method of confirming diagnosis $(\mathrm{n}=125)$

$\begin{array}{lll}\text { Bronchoscopy } & 51 & 40.8\end{array}$

$\begin{array}{lll}\text { Computed tomography-guided FNA } & 46 & 36.8\end{array}$

$\begin{array}{lll}\text { Pleural biopsy } & 10 & 8.0\end{array}$

$\begin{array}{lll}\text { Surgery } & 8 & 6.4\end{array}$

Brain biopsy $\quad 3 \quad 2.4$

Lymph node FNA $\quad 2 \quad 1.6$

$\begin{array}{lll}\text { Thoracocentesis } & 2 & 1.6\end{array}$

$\begin{array}{lll}\text { Ultrasound-guided FNA } & 1 & 0.8\end{array}$

$\begin{array}{lll}\text { Sputum cytology } & 1 & 0.8\end{array}$

Mediastinoscopy $\quad 1 \quad 0.8$

a Patients could have more than 1 symptom; denominators were different according to the symptom. $F N A=$ fine-needle aspiration. 


\begin{tabular}{lccccc}
\hline Table 3 Major histological types of lung cancer in Qatar by patient's nationality \\
\cline { 2 - 6 } Type & Qatari $(\boldsymbol{n}=\mathbf{6 6})^{\mathrm{a}}$ & Non-Qatari $(\boldsymbol{n}=\mathbf{1 2 1})^{\mathrm{a}}$ & Overall \\
& No. & $\%$ & No. & $\%$ & $\%$ \\
Adenocarcinoma & 32 & 48.5 & 50 & 41.3 & 43.9 \\
Squamous cell carcinoma & 13 & 19.7 & 34 & 28.1 & 25.8 \\
Small cell & 5 & 7.6 & 11 & 9.1 & 9.1 \\
Unspecified non-small cell & 6 & 9.1 & 12 & 9.9 & 10.6 \\
Large cell & 6 & 9.1 & 8 & 6.6 & 7.6 \\
Carcinoid & - & - & - & - & 1.5 \\
Sarcoma & - & - & - & - & 1.0 \\
Neuroendocrine (unspecified) & - & - & - & - & 0.5 \\
\hline
\end{tabular}

${ }^{a}$ Cases of unknown nationality or histopathological type were excluded.

patients (33.0\%) had already died while in Qatar. The median duration of survival (from time of diagnosis) for those who died was 4 months (mean 7.4).

There were 18 patients (8.9\%) who underwent surgery and 76 who (37.4\%) did not have surgical treatment (data on surgical treatment were missing for 109 patients). Chemotherapy was given to 56 patients (27.6\%) in Qatar and 36 patients (17.7\%) did not receive chemotherapy (data on chemotherapy treatment were missing for 111 patients). Radiotherapy was given to 32 patients (15.8\%) and 59 (29.1\%) did not receive radiotherapy (data on radiotherapy treatment were missing for 112 patients).

\section{Discussion}

The epidemiology and clinical course of lung cancer have been well studied in many countries. Although a previous study was performed to estimate the incidence oflung cancer in Gulf Cooperation Council (GCC) countries, which includes Qatar [6], to our knowledge, the present study is the first to determine the detailed epidemiological and clinical characteristics of this type of cancer in Qatar. We are confident that the results of this study are a true representation of lung cancer status. First, all lung cancer cases in Qatar are referred to our 2 hospitals for management and, secondly, we have a single central histopathology laboratory that reports immediately any histologically-confirmed lung cancer case to the national cancer registry.

The age-standardized incidence rate for lung cancer in males in Qatar (15.2 per 100000$)$ was higher than most of the other GCC countries (8.4, 7.2, 4.8 and 13.8 per 100000 for Oman, United Arab Emirates, Saudi Arabia and Kuwait respectively), except Bahrain (34.3 per $100000)[6]$.

As in many other countries, lung cancer, was very rare in Qatar before the age of 40 years, with $93.5 \%$ of cases diagnosed after the age of 40 years and $51.0 \%$ diagnosed at age 50-69 years.

A great majority of the patients $(82.5 \%)$ in our study were current smokers or ex-smokers at the time of diagnosis. This is not surprising in view of the etiological role of smoking in lung cancer and in a country with a smoking prevalence of $37 \%$ [3]. Lung cancer in Qatar mostly affected the male population ( $88.6 \%$ of cases). It is a global observation that lung cancer has a higher incidence in men that in women $[7,8]$. However, the sex ratio of almost 8:1 observed in Qatar is one of the highest in the world. Three reasons may be responsible for this high ratio. First, smoking among women in Qatar is socially unacceptable; in a recent study of cigarette smoking habits among the Qatari population, only $6.9 \%$ of the studied female population were smokers compared with $42.1 \%$ of males [3]. Second, males constitute the vast majority of the expatriate labour force in Qatar, among whom a high prevalence of smoking was noted [3]. Third, the structure of the population as a whole shows more males in Qatar than females, with a male to female ratio among Qatari population of 2:1 [2]. It is well known that patterns of histological types of lung cancer have changed over time and smoking is linked to all the major types of lung cancer [9].

In the United States of America and many other countries, adenocarcinoma has become the most commonly diagnosed type of lung cancer [10]. In Europe, despite squamous cell carcinoma remaining the most predominant cell type, the rates of adenocarcinoma have increased steadily over time $[11,12]$. In the current study, adenocarcinoma was the most frequently encountered histological type and accounted for about $44 \%$ of all lung cancer subtypes. Surprisingly, this finding is different from the findings in other GCC countries, where squamous cell carcinoma is still the most frequently diagnosed histological type [6]. Further analysis of histologicaltypes by nationality revealed that adenocarcinoma predominated in both Qatari natives and expatriates. Some hypotheses, such as the changes in the characteristics of cigarettes and the consequent changes in the doses of carcinogens inhaled, the advances in diagnostic techniques for lung cancer and the possible role of occupational exposure and pollution, have been postulated to explain the recent shift in histopathology $[7,10]$. Nevertheless, the predominance of adenocarcinoma among lung cancer types in Qatar and squamous cell carcinoma in other neighbouring GCC counties is a matter of interest that may be addressed in future studies in the Gulf area.

About $8 \%$ ofourpatientswereasymptomatic at the time of diagnosis and the lung cancer was suspected because of 
an abnormal chest radiograph. This percentage is slightly higher than reported in studies from other countries [13]. All foreigners wishing to stay in Qatar for more than 1 month are subjected to screening for communicable diseases, particularly tuberculosis. Chest radiograph is routinely performed for this reason. This might have contributed to the higher percentage of asymptomatic patients with lung cancer in Qatar. Our finding that $70 \%$ of these asymptomatic patients were expatriates augments this assumption. Our data are comparable to world epidemiological patterns, in which most patients are diagnosed with more advanced tumours (stage IIIB and IV) [14-16].

Ourstudy has limitations inherent in a retrospective study. The contribution of environmental risk factors other than smoking could not be ascertained in this study. Qatar is currently witnessing an industrial revolution and therefore the association between lung cancer and different environmental risks and occupational exposure may be a fruitful area for prospective studies on lung cancer in this country. As previously mentioned, the majority of our patients were expatriates who returned to their countries after diagnosis. Therefore, a high rate of loss of follow-up after diagnosis, with consequent lack of information on treatment and survival and mortality rates, is a major limitation of this study.

\section{Acknowledgements}

The authors would like to thank Dr Tasleem Raza (Senior Consultant Pulmonologist) for his valuable comments during the preparation of this work.

\section{References}

1. Brambilla E et al. The new World Health Organization classification of lung tumors. European respiratory journal, 2001, 18:1059-68.

2. Qatar in figures. Annual statistical abstract, 25th issue. Doha, Qatar, General Secretariat for Development Planning, October 2006.

3. Al-Mulla A, Bener A. Cigarette smoking habits among Qatari population. Public health medicine, 2003, 4(3):41-4.

4. Fritz PC et al. International classification of diseases for oncology, 3rd ed. Geneva, World Health Organization, 2000.

5. Mountain CF. Revisions in the International System for Staging of Lung cancer. Chest, 1997, 111:1710-17.

6. Al-Hamdan $\mathrm{N}$ et al. The incidence of lung cancer in the Gulf Cooperation Council countries. Annals of Saudi medicine, 2006, 26(6):433-8.

7. Alberg AJ, Samet JM. Epidemiology of lung cancer. Chest, 2003, 123:21S-49S.

8. Bhurgri $Y$ et al. Patho-epidemiology of lung cancer in Karachi (1995-2002). Asian Pacific journal of cancer prevention, 2006, 7:60-4.

9. Chapter 2. Cancer. In: The health consequences of smoking. A report of the Surgeon General. US Surgeon General and Centers for Disease Control and Prevention [website] (http://www. cdc.gov/tobacco/data_statistics/sgr/2004/pdfs/chapter2. pdf, accessed 31 July 2009).

10. Thun MJ et al. Cigarette smoking and changes in the histopathology of lung cancer. Journal of the National Cancer Institute, 1997, 89:1580-6.

11. Janssen-Heijnen ML, Coebergh JW. The changing epidemiology of lung cancer in Europe. Lung cancer, 2003, 41(3):245-58.

12. Skuladottir $\mathrm{H}$, Olsen JH, Hirsch FR. Incidence of lung cancer in Denmark: historical and actual status. Lung cancer, 2000, 27:107-18.

13. Beckles MA et al. Initial evaluation of the patient with lung cancer. Chest, 2003, 123:97S-104S.

14. Younes RN et al. Nonsmall cell lung cancer: evaluation of 737 consecutive patients in a single institution. Revista do Hospital das Clínicas, 2004, 59(3):119-27.

15. Park BJ, Altorki NK. Diagnosis and management of early lung cancer. Surgical clinics of North America, 2002, 82(3):457-76.

16. Maruyama R et al. Lung cancer in patients younger than 40 years of age. Journal of surgical oncology, 2001, 77(3):208-12. 